\title{
ECONOMETRIC MODELING OF EXTERNAL FACTORS INFLUENCE ON INNOVATION ACTIVITY IN THE CASE OF REGIONAL HETEROGENEITY IN RUSSIA
}

\author{
Oleg Mariev, ${ }^{1}$ Andrey Pushkarev ${ }^{2}$
}

\begin{abstract}
Innovations are essential for international competitiveness. In this research study, we analyze factors that affect the involvement of Russian firms in the innovation process. Our objective is to find out which factors on a regional level are the most important for innovative activity that would allow for improving the innovation policy. We overview the main groups of factors that were considered to be significantly affecting innovations. We then proceed to analyze the regional-level data, and classify the Russian regions into three groups based on set of their characteristics. Our results suggest that currently the most important external determinants of innovation propensity for the Russian regions are the share of organizations that carried out scientific research, FDI, appropriate infrastructure and the quality of human capital. It implies that the innovation policy should focus mainly on these indicators. We also found substantial differences between regional groups, both in significance of the considered indicators and in their power. Based on the results, we propose several policy recommendations that would facilitate innovation activities of the Russian regions.
\end{abstract}

JEL Classification Numbers: O31, H20; DOI: http://dx.doi.org/10.12955/cbup.v5.943

UDC Classification: 338.2

Keywords: innovations, human capital, external factors, regional heterogeneity, econometric modelling, self-organizing map

\section{Introduction}

Currently, both in Russia and in many other countries, more attention is paid to the issue of innovation activity and how this activity is related to various economic indicators, both at the micro and meso levels. Nevertheless, according to many studies and reports, innovation activity in the country remains at a low level (i.e. Schwab, 2016; Kuznetsov, 2015).

This paper aims to uncover how the range of external factors affect the innovation activities in Russia. It is done by analyzing different economic and social regional indicators that, according to previous research, may affect the innovative activities.

The rest of the paper is organized as follows. Section 2 provides a brief literature review. Section 3 provides a detailed description of the dataset and empirical methods used in this research. Section 4 discusses the empirical results based on the Russian region level data and their policy implications. Section 5 concludes the paper.

\section{Literature review}

To find the most relevant factors for the empirical analysis that affect regional innovation activity we analyzed a number of papers that discuss similar problems. In this section, we will give a short summary of them. Modern research identifies a large number of potential factors that can influence the innovative development of a region. In order to organize a large number of available indicators, we divide them into several groups.

\section{Level of human capital in the region}

The research of Junge et al. (2012) highlights that the presence of highly qualified specialists in the region is a prerequisite for the development of innovative technologies and products, and their production. To attract specialists to the region and prevent the outflow of highly qualified personnel, a decent standard of living is necessary. Therefore, this group of indicators, in addition to various indicators of the level of education, also may include public spending on medicine and education, the level of crime, GRP, the level of unemployment, the balanced financial result of organizations, etc.

\section{Condition for competition development}

Currently, among economists, the prevailing view is that the active perception, development and introduction of new technologies requires competition between enterprises. In particular, Dezhina

\footnotetext{
${ }^{1}$ Graduate School of Economics and Management, Ural Federal University, Yekaterinburg, Russian Federation; Institute of Economics, Ural Branch of the Russian Academy of Sciences, Yekaterinburg, Russian Federation, olegmariev@ mail.ru

${ }^{2}$ Graduate School of Economics and Management, Ural Federal University, Yekaterinburg, Russian Federation, a.a.pushkarev@urfu.ru
} 
(2008), in the work on the role of the state, science and business in creating an innovation-oriented economy, emphasizes that one of the reasons for the reluctance of Russian companies to invest in $\mathrm{R} \& \mathrm{D}$ is the lack of competition and the monopoly of larger companies on various markets. Thus, according to the author, the Russian economy needs to diversify the size of firms. To represent this group of factors indicators reflecting the development of financial institutions and the share of small enterprises in the total number of enterprises in the region are included.

\section{Investment climate in the region}

The innovation process is impossible without investing. To assess the investment activity of the region, it is necessary to take into account not only the volumes of investments, but also their distribution by industries and sources of financing. The impact of increasing investment in fixed assets on innovation is not obvious. As presented by Shtercer (2005), physical capital and knowledge are mutually reinforcing factors that stimulate economic growth. As it is mentioned in the named research, there is also an alternative point of view according to which the increase in physical capital leads to economic growth only in the medium term, and, accordingly, cannot determine innovation activity, which in most cases has a long-term characteristic.

\section{Quality of the infrastructure}

A large number of works have been devoted to the study of the influence of the level of infrastructure development on welfare. For example, Calderon and Serven (2004) in their study confirmed the positive relationship between a developed infrastructure and an increase in GDP, and a reduction in inequality in the distribution of income at the country level. The level of infrastructure development in the region affects the transaction costs of enterprises, and accordingly, the market efficiency of innovative products, which, in turn, will affect the desire and ability to carry out R \& D. This group of factors includes such indicators as the volumes of cargo transportation, density of roads, number of telephone sets, etc.

\section{Degree of involvement of the region in foreign economic activity}

It is frequently mentioned that foreign economic activity and innovative activity in many respects are interconnected. On the one hand, without developing and introducing innovative products, domestic enterprises will not be able to compete in the world market. On the other hand, without developing the sphere of foreign economic relations, which is one of the main channels for technology transfer, it will be difficult for Russian organizations to raise the level of innovation activity. This group includes indicators that characterize the volume of exports/imports to near and far abroad; indicators of the number of agreements, the value of the subject matter of the agreement and the receipt/payment of exports/imports of technologies and services of a technical nature, foreign direct investment.

Foreign direct investment (FDI) in this case is not only a source of funds, but also one of the most important channels for technology transfer. However, it is necessary to take into account the industry specificity of FDI. Since one of the goals of the innovation process in Russia is reducing the share of raw-material oriented industries in GRP.

As an indicator of innovative development at the regional level, the number of granted patents for inventions has been chosen in this study. This indicator has a number of advantages. Firstly, it characterizes the effectiveness of the research sector, which is the main source of innovation. Secondly, this indicator can be considered objective, since the only source of information on the grant of patents for inventions in Russia is the Federal Service for Intellectual Property (Rospatent). Thirdly, this indicator is widely used in similar studies, demonstrating good results in reflecting the level of innovation activity (Gorodnikova et al., 2015).

We present a methodology for the econometric estimation in the next section.

\section{Data and econometric model}

As a statistical basis for the study, we used data from the Rosstat for 68 regions of Russia (regions with a small number of data were excluded from the sample) for the date range 2001-2014 published in official publications, as well as those contained in electronic databases.

However, taking into account the development heterogeneity of the Russian regions, the model was considered not only for the whole dataset, but also for individual groups formed according to certain indicators. For classification of the regions, self-organizing maps of Kohonen (SOM) were used. The 
application of SOK allows grouping the analyzed territorial objects in accordance with their characteristics in such a way that objects close in value of these characteristics in the original multidimensional feature space are next to each other on the plane. The use of this method has a number of advantages, in particular, it allows taking into account the complexity of the formation of regional socio-economic systems.

The criteria for assessing the degree of industrial development of the region were chosen as targets for this study, since a high level of industrial development of the region can serve as an indicator of the readiness of its transition to innovative development. Based on the selected five criteria (gross regional product per capita, gross fixed capital formation per capita, urban population share in the total population of the region, industrial production index (as an \% increase compared to the previous year), and the share of processing industries in the GRP), 68 regions were divided into three groups (see Figure 1, for indexing and more details see Appendix A).

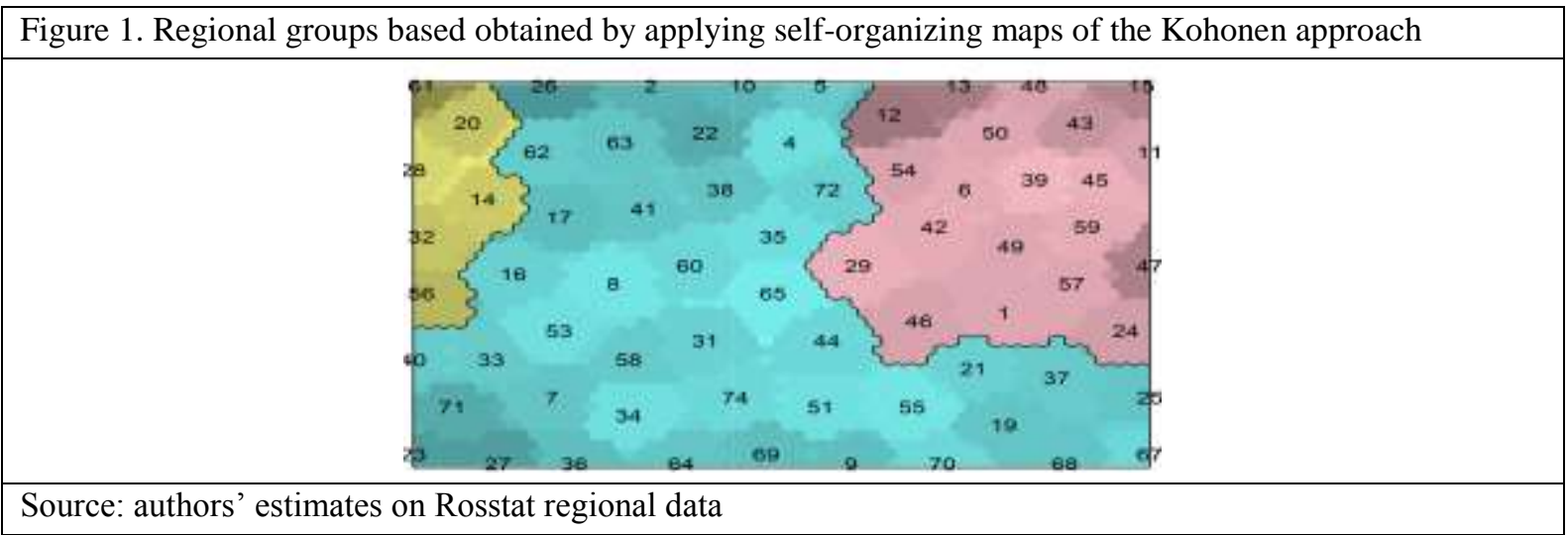

The first group incorporates most of the regions (62\%). One can say that this group is representation of the general situation in Russia, since all of the five indicators for the average value completely repeat the dynamics and only slightly exceed the average characteristics of the whole array of regions. For the regions included in the first group, there is a high level of well-being and a well-developed manufacturing industry; therefore, it can be assumed that they are the most innovative, as evidenced by statistical indicators. The presence of a direct relationship between the level of industrial and innovative development confirms the correctness of the hypothesis put forward earlier to determine the criteria for breaking down regions.

The second group of regions is characterized by a much lower level of welfare, a relatively low opportunity for the accumulation of fixed capita, and the lowest number of urban population. At the same time, these regions are characterized by the largest increase in industrial production. The level of innovative development is lower than the national average. Thus, we can assume that the regions of the second group have a good potential for innovative development, however, first they need to achieve a higher level of industrial production development.

The third group of regions, at first glance, is characterized by a much higher level of income and a good ability to accumulate fixed capital. However, taking into account the fact that this group includes regions mainly with harsh climatic conditions, in particular, the regions of the Far North and the Northeast of the country, it is necessary to understand that this indicator needs to be adjusted taking into account much higher prices ("the factor of the northern appreciation"). Being significantly lower than the national average, the index of industrial production and the share of manufacturing industry indicate a weak industrial development of the regions of this group. The level of innovative development is inferior to the Russian average. Therefore, stimulating innovation development in these regions is the most problematic. The inclusion of St. Petersburg into this group is associated with a high level of welfare in the region, which, unlike the rest of the group, is not explained by a much higher price level. Thus, the innovative development level of St. Petersburg, rather, is more similar to the regions of the first group.

To compile a generalized econometric model that takes into account all possible factors, we used the modified Cobb-Douglas knowledge generation function with fixed effects at the firm level: 


$$
y_{i, t}=\beta X_{i, t}+\alpha_{i}+\varepsilon_{i, t},
$$

Where $y_{i, t}$ is an explanatory variable characterizing the innovative activity of the region $\mathrm{i}$ in year $\mathrm{t}$;

$X_{i, t}$ is a vector of explanatory variables for the region $\mathrm{i}$ in year $\mathrm{t}$;

$\alpha_{i}$ is a region-level fixed effect.

\section{Results}

Results of the modelling are presented in Table 1 . They cover both overall model and three models for different regional groups.

\begin{tabular}{|c|c|c|c|c|}
\hline Variable & Overall & Group 1 & Group 2 & Group 3 \\
\hline Log of GRP & $0,42 * * *$ & - & $1,27^{* * *}$ & - \\
\hline $\begin{array}{l}\text { Log of revenues of the consolidated budget of a } \\
\text { constituent entity of the Russian Federation }\end{array}$ & $0,14 * * *$ & $0,24 * * *$ & - & - \\
\hline Log of gross fixed capital formation & $-0,09 * * *$ & $-0,08 * * *$ & $-0,12 * * *$ & - \\
\hline $\begin{array}{l}\text { Log of the number of registered crimes per } 100,000 \\
\text { people }\end{array}$ & - & - & $-0,48^{* *}$ & - \\
\hline $\begin{array}{l}\text { Share of organizations that carried out scientific research } \\
\text { and development in the total number of organizations }\end{array}$ & $3,97 * * *$ & $2,82 * * *$ & $9,43^{* * *}$ & $5,84 * *$ \\
\hline Log of the balanced financial result of enterprises & - & - & - & $0,05^{*}$ \\
\hline $\begin{array}{l}\text { Log of the public railway tracks density (km per 10,000 } \\
\text { sq. } \mathrm{km} \text { ) }\end{array}$ & $0,26^{* * *}$ & $0,16^{* *}$ & $1,08^{* * *}$ & - \\
\hline $\begin{array}{l}\text { Log of the public motor roads density (km per 10,000 sq. } \\
\mathrm{km} \text { ) }\end{array}$ & - & $0,05 * * *$ & - & $0,33^{*}$ \\
\hline $\begin{array}{l}\text { Share of credit institutions in the total number of } \\
\text { organizations in the region }\end{array}$ & - & - & $12,97^{*}$ & - \\
\hline $\begin{array}{l}\text { Log of the volume of investments in the fixed capital of } \\
\text { organizations: transport }\end{array}$ & $0,01 *$ & $0,02 * * *$ & $0,01 * *$ & - \\
\hline $\begin{array}{l}\text { Log of the volume of investments in fixed assets of } \\
\text { organizations: communication }\end{array}$ & - & $0,01^{*}$ & - & - \\
\hline $\begin{array}{l}\text { Share of graduates of state and municipal universities in } \\
\text { the total population of the region }\end{array}$ & $0,40^{*}$ & $0,68 * * *$ & $1,20^{*}$ & - \\
\hline $\begin{array}{l}\text { Log of the number of employees of organizations engaged } \\
\text { in research and development }\end{array}$ & $0,13^{* *}$ & $0,17 * * *$ & $0,26^{* *}$ & $1,33 * * *$ \\
\hline Log of FDI & $0,02 * * *$ & $0,02 * *$ & $0,02 * * *$ & $0,01 * *$ \\
\hline $\begin{array}{l}\text { Log of payment of funds for the import of technologies } \\
\text { and services }\end{array}$ & $-0,04 * * *$ & $-0,23 * * *$ & $-0,06^{* *}$ & - \\
\hline Number of observations & 952 & 588 & 280 & 84 \\
\hline $\mathrm{R}^{2}$ within & 0,79 & 0,82 & 0,88 & 0,55 \\
\hline \multicolumn{5}{|c|}{$\begin{array}{l}\text { Source: authors' estimates on Rosstat regional data } \\
* \text { Significant at } 10 \% ;{ }^{* *} \text { Significant at } 5 \% ;{ }^{* *} \text { Significant at } 1 \% .- \text { not included in the final model due to } \\
\text { insignificance }\end{array}$} \\
\hline
\end{tabular}


According to the results of the econometric estimation it can be concluded that out of each of the five initially formed groups of factors potentially affecting the innovation development of the regions, at least one indicator is included in the final model.

According to the test results, the model includes two factors that can be attributed to the field of international effects: foreign direct investment and payment of funds for the import of technologies and services. The significance of the first one may be because products and technologies created through direct foreign investment are often new. However, they may also represent imitations of already used technologies abroad, and in this case, accordingly, may not lead to an increase in the number of issued patents. The inverse relationship between the number of issued patents and the payment of funds for the import of technology is natural, and indicates a decrease in the innovative activity of enterprises with the possibility of borrowing technologies from abroad.

The positive correlation between the level of development of the regional economy (GRP) and the number of patents granted to inventions confirms the hypothesis that the most innovative regions of Russia also have the most developed economy.

The significance of the revenues of the regional budget can be explained as follows: an increase in the budget revenue component can increase the financing of various government programs aimed at improving human potential, infrastructure, and stimulating innovation activity.

The negative impact of gross fixed capital formation testifies to the hypothesis that the increase in intangible assets (including patents) and the increase in fixed assets are interchangeable. Enterprises investing in fixed assets divert a significant part of their income for this and, due to financial constraints, they do not have the opportunity to invest in research and development in parallel.

The significance of infrastructure development is confirmed by the positive influence of the railway's density and investments in the transport industry. Improving the transport infrastructure has a positive impact on turnover, thereby increasing the potential sales markets, which is an important incentive in deciding whether to develop a new product.

The quality of human capital in the model is reflected by two variables (the share of graduates of state and municipal higher education institutes in the total population of the region, and the number of employees of organizations engaged in research and development), which speaks of the exceptional importance of human resources development for innovative development. A direct and rather strong relationship between the share of organizations that have performed scientific research and development, in the total number of organizations, and the number of issued patents indicates a high degree of effectiveness of research activities. In other words, a large number of organizations engaged in $\mathrm{R} \& \mathrm{D}$ achieve the desired result, which is the receipt of a patent. Therefore, further investments in this fields contributes to the emergence of innovations.

Analysis of separate regional groups also shows several noteworthy results. The significance of the logarithm of revenues of the consolidated budget for the regions of the first group indicates that in these regions the state is most active in supporting innovation development through various programs financed (partly) by state funds. It can also be assumed that the amount of investment in the fixed capital of communication industry enterprises turned out to be significant only for the regions of the first group due to the already achieved high enough level of technology development in comparison with other regions.

The significance of the balanced financial result of enterprises for the regions of the third group indicates that innovation activity is carried out, first of all, at the expense of the profit of organizations. This is facilitated by the inadequate development of financial institutions and, consequently, the inaccessibility of the fund for borrowing. Another feature of this group is the strong significance of this indicator of human development, such as the number of employees of organizations engaged in research. Due to severe climatic conditions and the low level of social and economic development, the regions of this group are unattractive for young specialists, which leads to a shortage of qualified scientists and researchers. Thus, with low patent activity in general, an increase in the number of researchers leads to a substantial increase in the number of issued patents.

It can be concluded that each group has individual characteristics that manifest themselves either in the degree of influence of a factor or in the absence/presence of its influence, which highlights the need to improve regional economic policies to stimulate innovation in specific regions. 
However, there are also common factors for all regions that determine their innovative development, as evidenced by the high explanatory power of the general model of factors applied to the regions. Such indicators include the share of organizations that carried out scientific research and development in the total number of organizations; logarithm of the number of employees of organizations engaged in research and development; logarithm of direct foreign investments.

At the same time, the absolute values of the coefficients for the first two named variables show a difference in the power of their influence in regions of different groups. The third factor, foreign direct investment, influences positively and equally on the innovation activity of region groups, which necessitates its further detailed study with the aim of stimulating economic policy at various levels.

\section{Conclusion}

To sum up, in this research we have analyzed effects of different regional level factors on innovation activities. The results suggest that indicators, such as FDI, regional budget revenue, GRP, infrastructure development level and quality of human capital have a positive effect on the number of patents granted. Therefore, it may be beneficial for policies to target fields that these indicators represent, when aiming to increase innovation activity.

Additionally, we find that there are substantial differences between regional groups. For example, the group of Northern regions shows weaker correlation with most of the indicators however, significant ones have a stronger effect on innovation output than in all other regions. Thus, policy should be adjusted with these specialties in mind. We also find that there are several generally significant indicators, such as share of organizations that carried out scientific research and development in the total number of organizations; logarithm of the number of employees of organizations engaged in research and development; and logarithm of direct foreign investments. This means that federal policy should target these common traits first.

As prospects for further research, it would be beneficial to construct a model that would include not only factors on a regional level, but also at the level of separate firms. It would increase the overall quality of the model and provide better understanding, which firms the government should target as the main innovators and how exactly they could be supported.

\section{Acknowledgements}

This research was supported by the Russian Scientific Fund grant No. 15-18-10014 "Projection of optimal socio-economic systems in turbulence of external and internal environment".

\section{References}

Dezhina I.G.(2008) "State, science and business in the innovation system of Russia“, Dezhina IG, Kiseleva V.V. - Moscow: IET, $227 \mathrm{p}$.

Fritsch M., Aamoucke R. (2013) "Regional public research, higher education, and innovative start-ups: an empirical investigation" Small Business Economics, Vol. 41, pp. 865-885.

Gorodnikova N. et al. (2015) Innovation activity indicators - 2015, Moscow, High School Of Economics, 321.

Junge, M., Severgnini, B., Srensen, A. (2012) "Evidence on the Impact of Education on Innovation and Productivity", Working Papers from Copenhagen Business School, 2, pp 1-31.

Kirner E., Kinkel S., Jaeger A. (2009) "Innovation paths and the innovation performance of low-technology firms: An empirical analysis of German industry“, Research Policy, Vol. 38, pp. 447-458.

Kuznetsov E. (2015) National Report on innovations in Russia 2015. Moscow, Ministry of economic development , 146 (In Russian).

L. Serven, C. Calderon. (2004) "The effects of infrastructure development on growth and income distribution“, World Bank Policy Research Working Paper, № 3400, pp. 27-31.

Schwab, K. (2016) The Global Competitiveness Report 2015-2016, Geneva, The World Economic Forum, 403.

Shtertser T.A. (2005) "The empirical analysis of factors of innovative activity in the subjects of the Russian Federation" NSU Herald, Vol. 5. Issue 2, pp. 103-104.

Srholec M. (2011). "A multilevel analysis of innovation in developing countries“, Industrial and Corporate Change, Vol. 20, Issue 6, pp. 1539-1569. 


\section{Appendix A: Groups of regions and their indexes}

Group 1: Amur Region (2), Astrakhan Region (4), Belgorod Region (5), Chelyabinsk Region (7), Irkutsk Region (8), Ivanovo Region (9), Jewish Autonomous Region (10), Kemerovo Region (16 ), Khabarovsk Territory (17), Kirov Region (19), Kostroma Region (21), Krasnodar Territory (22), Krasnoyarsk Territory (23), Kursk Region (25), Leningrad Region (26), Lipetsk Region (27), Moscow Region (31), Nizhny Novgorod Region (33), Novgorod Region (34), Novosibirsk Region (35), Omsk Region (36), Orel Region (37), Orenburg Region (38), Perm Territory (40), Primorsky Territory (41), Republic of Bashkortostan (44), Ryazan Region (51), Samara Region (53), Smolensk Region (55), Sverdlovsk Region (58), Republic of Karelia (60), Republic of Tatarstan (62), Tomsk Region (63), Tula Region (64), Tver Region (65), Udmurt Republic (67), Ulyanovsk Region (68), Vladimir Region (69), Volgograd Region (70), Vologda Region (71 ), Voronezh Region (72), Yaroslavl Region (74).

Group 2: Altai Territory (1), Pskov Region (42), Republic of Adygea (43), Republic of Buryatia (45), Chuvash Republic (46), Republic of Dagestan (47), Republic of Mordovia (48), Republic of North Ossetia-Alania (49), Rostov Region (50), Saratov Region (54), Stavropol Territory (57), Tambov Region (59).

Group 3: Kamchatka Territory (14), Komi Republic (20), Magadan Region (28), St. Petersburg (56), Republic of Sakha (Yakutia) (61). 